Chapter 4

\title{
New Candidate Genes in Atrial Fibrillation Polymorphisms of the Alpha 2-Beta-Adrenoceptor and the Endothelial NO Synthase Genes in Atrial Fibrillation of Different Etiological Origins
}

\author{
Svetlana Nikulina, Vladimir Shulman, \\ Ksenya Dudkina, Anna Chernova and \\ Oksana Gavrilyuk \\ Additional information is available at the end of the chapter \\ http://dx.doi.org/10.5772/53527
}

\section{Introduction}

Molecular and genetic bases of atherosclerosis, cardiomyopathy, hypertension are the most studied among cardiovascular diseases. Recently, search for genetic markers associated with various rhythm disorders and conduction attracts researchers. The greatest attention is paid to the genetic aspects of atrial fibrillation as the most frequent and dangerous arrhythmia.

Atrial fibrillation represents the most common type of arrhythmia in clinical practice. The prevalence of atrial fibrillation is $0.4 \%$ in the general population and it increases with age [1]. According to the Framingham study atrial fibrillation doubles mortality in cardiac patients and is responsible for $1 \backslash 3$ thromboembolic episodes [2-4]. That's why finding of genealogical and genetic aspects of atrial fibrillation predictors of its occurrence is relevant and offers opportunities for early diagnosis and timely prevention of this pathology.

In most cases, this rhythm disorder is secondary, i.e. it's caused by a disease. But at least in the $1 \backslash 3$ cases etiology of atrial fibrillation cannot be established. Such arrhythmia is known to refer to the terms - idiopathic atrial fibrillation, primary atrial fibrillation, or "isolated atrial fibrillation» (lone atrial fibrillation). It is believed that a significant number of primary atrial fibrillation cases are caused by a hereditary factor [5-10]. However, even in the secondary atrial fibrillation a hereditary component is not excluded in the development of arrhythmia. In the 90 s of the 20th century many papers associated with the genealogy of atrial 
fibrillation described some families whose members had atrial fibrillation and / or atrial flutter $[7-9,11,12]$.

Molecular researches of AF are concentrated generally in 2 directions: 1. Identification of genes which mutations lead to arrhythmia (inheritance of such mutations occurs according to the classical Mendel type). 2. Studying of polymorphisms of various genes, so-called genes of susceptibility or genes - candidates.

In this regard, some of the most promising genetic markers are polymorphisms of gene alpha 2-beta-adrenoceptor (ADRA2V). Gene ADRA2V is located on the long arm of chromosome 2 (2q11.2), it has no introns. It encodes a2 $\beta$-adrenergic receptor [13]. Adrenergic receptors - a class of receptors coupled to G-proteins activated by catecholamines [13, 14]. There are at least four groups of receptors that differ in their mediated effects, localization and affinity for different substances: alpha-1, alpha 2, beta 1 and beta- 2 adrenergic receptors $[15,16]$. A2 - adrenergic receptors include three subtypes: $\alpha 2 \mathrm{a}$, a2 $\beta$ and $\alpha 2 \mathrm{c}$ [17].

All these proteins have a similar structure and are associated with G-protein [13]. Receptors of $\alpha 2$ family are important components of vegetative nervous system and provide a physiological response to sympathetic stimulation. A role of the sympathoadrenal stimulation of the atria in the pathogenesis of AF was shown in the works of P. Coumel et al. [18] in 1982.

Molecules of nitric oxide (NO) can play a definite role in the pathogenesis of AF. Nitric oxide in the human body is continuously produced by fermentation from L - arginine and serves as a universal messenger inside and intercellular signaling [19]. The catalyst of this reaction is synthase NO (NO-synthase, or NOS, the enzyme code 1.14.13.39) [19]. Influenced by NO-synthase oxidation of L - arginine and nitric oxide synthesis in endothelial cells of blood vessels take place. Then, getting out of endothelial cells into the smooth muscle cells, nitric oxide activates soluble guanylate cyclase, that leads to increased level of cyclic GMP, activation of cyclic GMP - dependent protein kinases, changes in calcium concentration and sensitivity of conducting cardiac myocytes receptors to the level of catecholamines. In 2005 M. Kim showed that the decrease in the production of NO-synthase can cause oxidative stress and lead to changes in myocardial conduction system, thereby contributing to the development of AF [20]. Polymorphism rs1799983 in exon 7 of the gene NOS3, replacement of $\mathrm{G}$ to $\mathrm{T}$ in position 894 of the nucleotide sequence leads to the replacement glu298-to-asp (E298D) in the amino acid sequence. So far, the influence of polymorphisms of gene ADRA2B and gene of endothelial NO-synthase on the development of atrial fibrillation has not been investigated.

\subsection{Genealogical and genetic aspects of atrial fibrillation}

The first familial cases of atrial fibrillation were described in 1943 [21]. In 1950 for the first time Gould pointed out a significant role of heredity in the atrial fibrillation development. He described the family susceptibility to atrial fibrillation, monitored the history of atrial fibrillation in several generations of this family for 36 years [22]. In 1998 T. Tikanoja et al. [23] have published data about the development of familial atrial fibrillation in two fetuses at 23 and 25 weeks of fetal development, and both babies were born with ongoing atrial fibrilla- 
tion. Researchers have shown particular interest to families that had an accumulation of intraventricular conduction disturbances, combined with a variety of tachyarrhythmias. Families whose members in several generations suffered from atrial fibrillation and/or atrial flutter in a combination with a blockade of various branches of His bundle or atrio-ventricular block [24-27] were described.

C.S. Fox et al. indicated that atrial fibrillation in the parents increases the risk of atrial fibrillation for posterity. Among the examined 2243 patients with atrial fibrillation 681patients $(30 \%)$ had at least one parent with the registered atrial fibrillation [9]. Postulational piority of the autosomal dominant model atrial fibrillation belongs to J. Girona et al. (1997). They presented two families in which 20 out of 70 members had paroxysmal or persistent atrial fibrillation [28]. A. Gillor, E. Korsch in 1992 [29] described a family case of idiopathic atrial flutter. In this family, two male children were diagnosed with atrial flutter; they were the third and sixth children of seven. Other five children were girls. Two daughters died, the first daughter died at the age of twenty days, parents do not know the cause of death, the fourth - at the age of 5 years, probably from meningitis.

In 1996 French scientists P. Poret, P. Mabo, C. Deplace et al. studied a family with congenital tachyarrhythmia. In three generations five members of the family were diagnosed with idiopathic atrial fibrillation since the young age. The examination of the sick relatives revealed hypertrophy of both atria, mitral and tricuspid regurgitation [27]. In $1997 \mathrm{R}$. Brugada et al. $[30,31]$ carried out clinical, electrophysiological and genetic study of three Spanish families with atrial fibrillation.

Genetic analysis revealed that the gene responsible for atrial fibrillation in this family is localized on chromosome 10q in the area 10q22-24. Abnormal gene locus was placed between D10S1694 and D10S1786. The authors supposed that candidate genes of this pathology were genes of beta- adrenoreceptors (ADRB1), alpha- adrenoreceptors (ADRA2) and genes of Gprotein coupled receptor-kinase (GPRR5) as localized on the same chromosome 10 in locus 23 - 26. In these families atrial fibrillation was revealed in 21 out of 49 relatives. One of the sick relatives (II-8) died at the age of 68 from stroke. The other relative (III-2) with paroxysmal AF since 20 years' age, died suddenly at the age of 36 , but an autopsy was not performed. 18 out of 19 living family members had chronic atrial fibrillation and 1 - paroxysmal atrial fibrillation.

Finally, Chinese scientists $\mathrm{H}$. Yang et al. identified 2 genes responsible for heredity of atrial fibrillation. They appeared to be genes of proteins of potassium channels in myocytes. In particular, H. Yang et al. [32] reported about replacement of arginine to cysteine in position 27 of gene KCNE2 on chromosome 21q22.1-22, encoding the beta subunit of potassium channels. These mutations appeared in 2 out of 28 examined Chinese families with familial atrial fibrillation. H. Yang et al. identified the mutation of (S140G) gene on chromosome 11p15.5, encoding the alpha subunit of the cardiac potassium channel. Atrial fibrillation occurrence in these cases is due to the fact that in these genes function of the corresponding potassium channels increases, leading to the shortening of potential action and atrial effective refractory period. It should be recalled that paroxysmal atrial fibrillation is one of the major phenotypic manifestations of the syndrome of short interval QT, in which the func- 
tion of potassium channels is increased. Thus, the data of Chinese researchers suggest that certain variants of familial atrial fibrillation can be attributed to channelopathies.

H. Yang et al. [32] in their work also showed an increase in the amount of protein connexin 43 with atrial fibrillation, the highest in the left atrium. Christiansen J. et al. [33] found that mutation in gene 1q21.1, which leads to a decrease in connexin 40, promotes the development of abnormalities of the aortic arch with atrial fibrillation. Somatic mutations in the gene encoding gap - junction protein connexin 40 (GJA5), myocardial protein involved in the coordination of the electrical activity of the atria, can be a cause of idiopathic atrial fibrillation in some cases [34].

"A significant part of patients have no obvious cause for the development of atrial fibrillation and it is possible that $1 / 3$ of these cases actually occurs due to mutations in GJA5 ", Michael R. and H. Gollob wrote (University of Ottawa Heart Institute, Ontario, Canada). The findings, published in New England Journal of Medicine, are based on analysis of GJA5 in cardiac tissue and lymphocytes taken from 15 patients with idiopathic atrial fibrillation. Four out of all these patients had heterozygous mutations in GJA5. Three patients had mutations in heart tissue but not in lymphocytes, that indicates a somatic origin of the defects. The fourth patient's mutation was detected in both types of cells that suggest an embryonic mutation. Dr. H. Gollob believes that connexin 40 may become the object of search for new drugs to treat atrial fibrillation. The findings, according to the authors' opinion, suggest that the so-called idiopathic atrial fibrillation may have a genetic basis in the form of the defect, limited by the sick tissue.

By the present moment a large quantity of data is stored that activity of renin-angiotensinaldosterone system (RAAS) is of great importance for formation of this peculiar «cardiomyopathies of auricles». A key component of RAAS, significantly affecting its activity through the synthesis of angiotensin - II is a angiotensin-converting enzyme (ACE). ACE gene, located on chromosome 17q23, consists of 26 exons and 25 introns [35, 36]. ACE gene polymorphism concerns a fragment of intron 16 and it is connected with the insertion / deletion of 287 pairs of nucleotides and determines three genotypes - I / I, D / D and I / D. V.I. Tseluyko et al. showed that ACE levels in plasma are significantly higher in patients with genotype D / D than in genotype I / I. Heterozygotes have intermediate levels of ACE [37]. L.O. Minushkina, E.S. Gorshkova et al. (2010) studied association of genes $\beta$-adrenoceptors of types 1, 2, and 3 (ADRB1, ADRB2, ADRB3), connexin (CX40) and a voltage - locked potassium channel of type 2 ( $\mathrm{KCNH} 2$ ) with the occurrence of atrial fibrillation in patients with hypertension. This study shows that for polymorphic marker Trp64Arg of gene ADRB3 Trp allele frequency was significantly higher and the frequency of the Arg allele was significantly lower in patients with atrial fibrillation. In patients with atrial fibrillation frequency of the homozygous genotypes Arg / Arg appeared to be significantly less [38, 39].

According to the analysis conducted by J.D. Roberts, M.H. Michael, M.H. Gollob [10] at present a connection between atrial fibrillation and gene polymorphism of ion channels subunits KCNQ1 [40], KCNA5 [41], KCNE2, KCNJ2, SCN5A, GJA5, NPPA is established. [10]. Several recent studies have focused on the association between the promoter polymorphisms $786 \mathrm{~T} / \mathrm{C}$ of the endothelial nitric oxide synthase (eNOS) gene and susceptibility to at- 
rial fibrillation (AF); however, results have been conflicting. In subgroup analysis, stratified by ethnicity, we observed a positive association between the eNOS 786T/C polymorphism and AF risk among Caucasians but not among mixed populations[42]. Meta-analysis suggests that there is insufficient evidence to demonstrate an association between ACE I/D polymorphism and AF risk. However, there seems to be a significant association between ACE I/D gene polymorphic variation and AF in patients with hypertension [43].

\section{Results}

\subsection{Clinical polymorphism of atrial fibrillation in probands and their relatives}

A total of 100 probands with atrial fibrillation and 150 of their relatives of the I ${ }^{\text {st, }}$ II nd and III ${ }^{\text {rd }}$ degree of relationship were examined. These families composed the study base for our research.

The probands were searched during the course of their in-patient and out-patient treatment in the Cardiological center of the Krasnoyarsk Regional clinical hospital № 20 named after I.S. Berzon. The patients' relatives were examined during doctors' home visits and subsequent check-ups in the Cardiological center. We also studied 91 patients without electrocardiographic manifestations of cardio-vascular diseases (control group).

The families of the probands with atrial fibrillation were divided into two groups according to the atrial fibrillation etiology:

1. Families of the probands with primary atrial fibrillation, in which clinical and instrumental examination revealed no evident cause-effect relation with any cardio-vascular diseases as well as other diseases which may have atrial fibrillation as a complication;

2. Families of the probands with secondary atrial fibrillation, in which the onset of this dysrhythmia was due to specific diseases as ischemic heart disease, arterial hypertension, dilated cardiomyopathy, gastroesophageal hernia and thyrotoxicosis.

The first group (families of the probands with primary atrial fibrillation) included 40 probands ( 24 males and 16 females) and 79 of their relatives (23 males and 56 females), and the second one (families of the probands with secondary atrial fibrillation) included 60 probands (28 males and 32 females) and 71 of their relatives (20 males and 51 females). Atrial fibrillation was revealed in 5 out of 79 relatives of the first group and in 1 out of 71 relatives of the second group. Differentiated clinical and electrocardiographic characteristics of the patients with primary atrial fibrillation are specified in Table 1.

Paroxysmal atrial fibrillation was revealed in 38 probands with primary atrial fibrillation $(95,0 \pm 3,4 \%)$ and paroxysmal atrial flutter was revealed in 2 persons $(5,0 \pm 3,4 \%)$. Among the sick relatives with primary atrial fibrillation (5 persons) paroxysmal atrial fibrillation was revealed in 5 persons $(100 \%)$. 


\begin{tabular}{|c|c|c|c|c|}
\hline \multirow{2}{*}{ Atrial fibrillation type } & $\begin{array}{c}\text { Probands with primary atrial } \\
\text { fibrillation } \mathbf{( n = 4 0 )}\end{array}$ & $\begin{array}{c}\text { Probands'sick relatives } \\
(\mathbf{n}=\mathbf{5})\end{array}$ \\
\cline { 2 - 5 } & $\begin{array}{c}\text { Absolute } \\
\text { value }\end{array}$ & $\begin{array}{c}\text { Absolute } \\
\text { value }\end{array}$ & 100 \\
\hline Paroxysmal atrial fibrillation & 38 & $95,0 \pm 3,4$ & 5 & 0 \\
\hline Paroxysmal atrial fibrillation - atrial flutter & 2 & $5,0 \pm 3,4$ & 0 & 0 \\
\hline
\end{tabular}

Table 1. Differentiated clinical and electrocardiographic characteristics of the patients with primary atrial fibrillation

\begin{tabular}{|c|c|c|c|c|}
\hline \multirow{2}{*}{ Atrial fibrillation type } & $\begin{array}{c}\text { Probands with secondary } \\
\text { atrial fibrillation }(\mathbf{n = 6 0})\end{array}$ & $\begin{array}{c}\text { Probands'sick relatives } \\
(\mathbf{n}=\mathbf{1})\end{array}$ \\
\cline { 2 - 5 } & $\begin{array}{c}\text { Absolute } \\
\text { value }\end{array}$ & $\begin{array}{c}\text { Absolute } \\
\text { value }\end{array}$ & 1 & 100 \\
\hline Paroxysmal atrial fibrillation & 38 & $63,3 \pm 6,2$ & 0 & 0 \\
\hline Paroxysmal atrial fibrillation - atrial flutter & 6 & $10,0 \pm 3,9$ & 0 & 0 \\
\hline flutter summarily & 44 & $73,3 \pm 5,7$ & 0 & 0 \\
\hline Chronic atrial fibrillation & 10 & $16,6 \pm 4,8$ & 0 & 0 \\
\hline Persistent atrial fibrillation & 6 & $10,0 \pm 3,9$ & 0 & 0 \\
\hline
\end{tabular}

Table 2. Differentiated clinical and electrocardiographic characteristics of the patients with secondary atrial fibrillation

According to Table 2, in the group of probands with secondary atrial fibrillation paroxysmal atrial fibrillation was diagnosed in 38 out of 60 patients $(63,3 \pm 6,2 \%)$, paroxysmal atrial flutter - in 6 persons $(10,0 \pm 3,9 \%)$. In total paroxysmal atrial fibrillation and atrial fibrillation - atrial flutter was observed in $73,3 \pm 5,7 \%$ of the probands with secondary atrial fibrillation. Chronic atrial fibrillation was revealed in 10 patients $(16,6 \pm 4,8 \%)$, persistent atrial fibrillation - in 6 persons $(10,0 \pm 3,9 \%)$. Due to the small number of persons in these groups, the probands with chronic and persistent atrial fibrillation were integrated into one group (chronic and persistent atrial fibrillation), which included 16 patients $(26,6 \pm 5,7 \%)$.

Cardio-vascular pathology in the probands with idiopathic and secondary atrial fibrillation, as well as other diseases which have atrial fibrillation as a complication, are represented in Table 3. Namely, in 42 probands with secondary atrial fibrillation $(70,0 \pm 5,9 \%)$ we revealed ischemic heart disease (effort angina of II-III functional class) in 29 persons, which made $48,3 \pm 7,1 \%$ of the total of probands of this group, II ${ }^{\text {nd }}-$ III ${ }^{\text {rd }}$ functional class effort angina together with the III ${ }^{\text {rd }}$ stage hypertension- in 6 probands $(10,0 \pm 5,4 \%)$, postinfarction cardio- 
sclerosis - in 7 probands $(11,7 \pm 5,8 \%)$. The II ${ }^{\text {nd }}$ stage hypertension from the $1^{\text {st }}$ to the $3^{\text {rd }}$ degree was diagnosed in 12 probands $(20,0 \pm 5,2 \%)$, the III ${ }^{\text {rd }}$ stage hypertension from the $2^{\text {nd }}$ to the $3^{\text {rd }}$ degree was diagnosed in 4 persons $(6,7 \pm 3,2 \%)$, gastroesophageal hernia - in 1 person, the $2^{\text {nd }}$ degree nodular goiter with the appearance of euthyroidism as of the time of examination - in 1 person $(1,6 \pm 1,6 \%)$.

In a small number of cases cardio-vascular pathologies were diagnosed in the probands with idiopathic atrial fibrillation: in 7 persons $(17,5 \pm 6,0 \%)$ we diagnosed hypertension: 4 patients $(10,0 \pm 4,7 \%)$ had the $I^{\text {st }}$ stage hypertension of the $1^{\text {st }}$ degree, 3 patients $(7,5 \pm 4,2 \%)$ had the $I^{\text {nd }}$ stage hypertension of the $1^{\text {st- }}-2^{\text {nd }}$ degree, 4 probands $(10,0 \pm 4,7 \%)$ had ischemic heart disease (II ${ }^{\text {nd }}$ - III ${ }^{\text {rd }}$ functional class effort angina). However atrial fibrillation seizures in probands with primary atrial fibrillation were revealed long before the appearance of the first signs of ischemic heart disease and hypertension, therefore atrial fibrillation doesn't seem to be related to the revealed cardio-vascular diseases. As for the probands with secondary atrial fibrillation, they showed temporal relation between the manifestations of the underlying disease and subsequent appearance of atrial fibrillation.

\begin{tabular}{|c|c|c|c|c|c|}
\hline \multirow[t]{2}{*}{ Disorders } & \multicolumn{2}{|c|}{$\begin{array}{l}\text { Probands with idiopathic } \\
\text { atrial fibrillation } \\
\qquad(\mathrm{n}=40)\end{array}$} & \multicolumn{2}{|c|}{$\begin{array}{l}\text { Probands with the } \\
\text { secondary atrial } \\
\text { fibrillation } \\
(n=60)\end{array}$} & \multirow[t]{2}{*}{$\mathrm{p}$} \\
\hline & $\begin{array}{l}\text { Absolute } \\
\text { value }\end{array}$ & $\%$ & $\begin{array}{l}\text { Absolute } \\
\text { value }\end{array}$ & $\%$ & \\
\hline The Ist $_{\text {stage hypertension. }}$ & 4 & $10,0 \pm 4,7$ & 0 & 0 & $>0,05$ \\
\hline The IInd stage hypertension. & 3 & $7,5 \pm 4,2$ & 12 & $20,0 \pm 5,2$ & $>0,05$ \\
\hline The IIIrd stage hypertension. & 0 & 0 & 4 & $6,7 \pm 3,2$ & $>0,05$ \\
\hline $\begin{array}{l}\text { Ischemic heart disease combination }\left(\mathrm{II}^{\text {nd }}-\mathrm{III}^{\text {rd }}\right. \\
\text { functional class angina and the III }{ }^{\text {rd }} \text { stage } \\
\text { hypertension). }\end{array}$ & 0 & 0 & 6 & $10,0 \pm 3,9$ & $>0,05$ \\
\hline $\begin{array}{l}\text { Ischemic heart disease: postinfarction } \\
\text { cardiosclerosis. }\end{array}$ & 0 & 0 & 7 & $11,7 \pm 4,1$ & $>0,05$ \\
\hline $\begin{array}{l}\text { Ischemic heart disease: II }{ }^{\text {nd }} \text { - III }{ }^{\text {rd }} \text { functional } \\
\text { class angina. }\end{array}$ & 4 & $10,0 \pm 4,7$ & 29 & $48,3 \pm 6,5$ & $<0,005$ \\
\hline Gastroesophageal hernia. & 0 & 0 & 1 & $1,6 \pm 1,6$ & $>0,05$ \\
\hline $\begin{array}{l}\text { The } 2^{\text {nd }} \text { degree nodular goiter with the } \\
\text { appearance of euthyroidism as of the time of } \\
\text { examination. }\end{array}$ & 0 & 0 & 1 & $1,6 \pm 1,6$ & $>0,05$ \\
\hline
\end{tabular}

Note: Differences in the investigated parameters were calculated using the $x 2$ criterion.

Table 3. Cardio-vascular pathology in patients with idiopathic and secondary atrial fibrillation (\& other diseases which can cause atrial fibrillation) 
Therefore, summarizing the abovementioned, we come to the following conclusion.

In the first group (primary atrial fibrillation) paroxysmal atrial fibrillation was dominant (revealed in all the patients). In probands with secondary atrial fibrillation a significant prevalence of chronic/persistent atrial fibrillation was diagnosed (in 16 out of 60 persons $(26,6 \pm 5,7 \%)$.

In the probands with primary atrial fibrillation paroxysmal atrial fibrillation had been revealed long before any cardio-vascular diseases manifestations appeared.

\subsection{Polymorphism of the gene ADRA2B in probands with atrial fibrillation, their healthy relatives and persons of the control group}

In our work we investigated polymorphisms of the gene ADRA2B in patients with atrial fibrillation, their healthy relatives and persons from the control group. According to the results of PCR three sorts of genotypes ADRA2B in patients with AF, their healthy relatives and persons from the control group are revealed: I / I - homozygous by the insertion, I / D heterozygous, D / D - homozygous by the deletion. In patients with atrial fibrillation frequency of the homozygous genotype (D/D) made $8,5 \pm 2,7 \%$ (9 persons), whereas frequency of the heterozygous genotype (genotype I/D) made $50,9 \pm 4,9 \%$ (54 persons), frequency of the homozygous genotype in a rare allele (I/I) made 40,6 $6 \pm 4,8 \%$ (43 persons) (Table 4 ).

Frequency of the homozygous genotypes among the probands' healthy relatives appeared to be spread as follows: homozygous genotype in a frequent allele (D/D) made $11,8 \pm 2,7 \%$ (17 persons), heterozygous genotype (I/D) $-50,7 \pm 4,2 \%$ (73 persons), homozygous genotype in a rare allele (I/I) $-37,5 \pm 4,0 \%$ (54 persons) (Table 4).

\begin{tabular}{|c|c|c|c|c|c|c|c|c|c|}
\hline \multirow[t]{2}{*}{ Genotypes } & \multicolumn{2}{|c|}{$\begin{array}{l}\text { Patients with atrial } \\
\text { fibrillation } \\
\mathrm{N}=106\end{array}$} & \multicolumn{2}{|c|}{$\begin{array}{l}\text { Healthy relatives } \\
\qquad \mathrm{N}=144\end{array}$} & \multicolumn{2}{|c|}{$\begin{array}{l}\text { Control group } \\
\qquad \mathrm{N}=91\end{array}$} & \multirow{2}{*}{$\mathbf{p}_{1-2}$} & \multirow{2}{*}{$\mathbf{p}_{1-3}$} & \multirow{2}{*}{$\mathbf{p}_{2-3}$} \\
\hline & $\begin{array}{c}\text { Absolute } \\
\text { value }\end{array}$ & $\%$ & $\begin{array}{c}\text { Absolute } \\
\text { value }\end{array}$ & $\%$ & $\begin{array}{c}\text { Absolute } \\
\text { value }\end{array}$ & $\%$ & & & \\
\hline$D / D$ & 9 & $8,5 \pm 2,7$ & 17 & $11,8 \pm 2,7$ & 10 & $11 \pm 3,3$ & $p>0,05$ & $p>0,05$ & $p>0,05$ \\
\hline I/D & 54 & $50,9 \pm 4,9$ & 73 & $50,7 \pm 4,2$ & 58 & $63,7 \pm 5,0$ & $p>0,05$ & $p>0,05$ & $p>0,05$ \\
\hline $1 / 1$ & 43 & $40,6 \pm 4,8$ & 54 & $37,5 \pm 4,0$ & 23 & $25,3 \pm 4,6$ & $p>0,05$ & $p<0,05$ & $p>0,05$ \\
\hline
\end{tabular}

Note: Differences in the investigated parameters were calculated using the $x 2$ criterion.

Table 4. Frequency of the gene ADRA2B genotypes in probands with atrial fibrillation, their healthy relatives and persons of the control group.

In persons of the control group (D/D) frequency of the homozygous genotype made $11,0 \pm 3,3 \%$ (10 persons), frequency of the heterozygous genotype (genotype I/D) made $63,7 \pm 5,0 \%$ (58 persons), frequency of the homozygous genotype in a rare allele (I/I) made $25,3 \pm 4,6 \%$ (23 persons) (Table 4 ). 
A significant prevalence of homozygous genotype I/I in patients with AF $(40,6 \%)$ compared with the control group $(25,3 \%)(p=0,034)$ was established (Table 4, Fig.1).

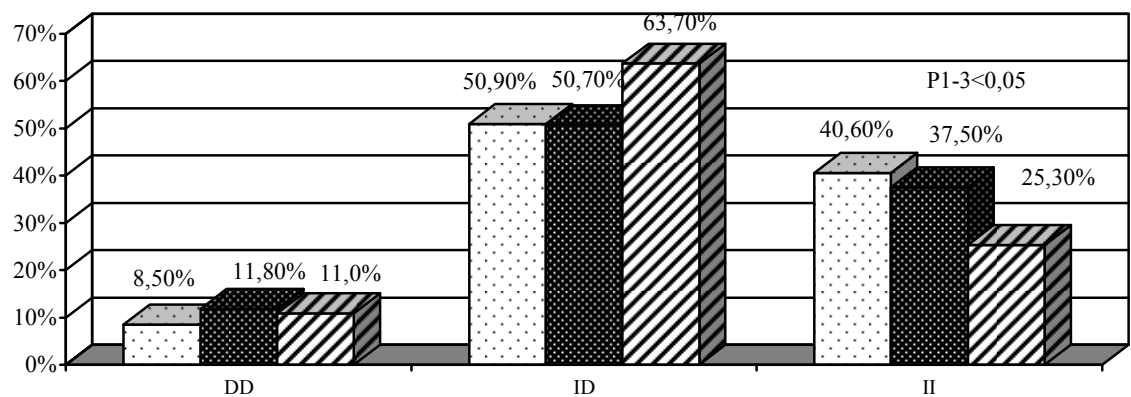

$\square 1$ Patients with atrial fibrillation (n=106) 2 Healthy relatives (n=144) 3 Control group (n=91)

Figure 1. Frequency of the gene ADRA2B genotypes in probands with atrial fibrillation, their healthy relatives and persons of the control group.

In patients with primary atrial fibrillation frequency of the homozygous genotypes (D/D) made $6,7 \pm 3,7 \%$ (3 persons), frequency of the heterozygous genotype (I/D) made $48,9 \pm 7,5 \%$ (22 persons), frequency of the homozygous genotype in a rare allele (I/I) made 44,4 $\pm 7,4 \%$ (20 persons) (Table 5). A significant prevalence of homozygous genotype I/I as compared with the control group $(25,3 \%)$ is established only in patients with primary atrial fibrillation $(44,4 \%)(p=0,039)$ (Table 5, Fig. 2).

\begin{tabular}{|c|c|c|c|c|c|c|c|c|c|}
\hline \multirow[t]{2}{*}{ Genotypes } & \multicolumn{2}{|c|}{$\begin{array}{l}\text { Patients with } \\
\text { primary atrial } \\
\text { fibrillation } \\
\mathrm{N}=45\end{array}$} & \multicolumn{2}{|c|}{$\begin{array}{l}\text { Healthy relatives } \\
\qquad \mathrm{N}=144\end{array}$} & \multicolumn{2}{|c|}{$\begin{array}{l}\text { Control group } \\
\qquad \mathrm{N}=91\end{array}$} & \multirow[t]{2}{*}{$\mathbf{p}_{1-2}$} & \multirow[t]{2}{*}{$\mathbf{p}_{1-3}$} & \multirow[t]{2}{*}{$\mathbf{p}_{2-3}$} \\
\hline & $\begin{array}{c}\text { Absolute } \\
\text { value }\end{array}$ & $\%$ & $\begin{array}{c}\text { Absolute } \\
\text { value }\end{array}$ & $\%$ & $\begin{array}{c}\text { Absolute } \\
\text { value }\end{array}$ & $\%$ & & & \\
\hline$D / D$ & 3 & $6,7 \pm 3,7$ & 17 & $11,8 \pm 2,7$ & 10 & $11 \pm 3,3$ & $p>0,05$ & $p>0,05$ & $p>0,05$ \\
\hline I/D & 22 & $48,9 \pm 7,5$ & 73 & $50,7 \pm 4,2$ & 58 & $63,7 \pm 5,0$ & $p>0,05$ & $p>0,05$ & $p>0,05$ \\
\hline $1 / 1$ & 20 & $44,4 \pm 7,4$ & 54 & $37,5 \pm 4,0$ & 23 & $25,3 \pm 4,6$ & $p>0,05$ & $p<0,05$ & $p>0,05$ \\
\hline
\end{tabular}

Note: Differences in the investigated parameters were calculated using the $x 2$ criterion.

Table 5. Frequency of the gene ADRA2B genotypes in patients with primary atrial fibrillation, their healthy relatives and persons of the control group. 


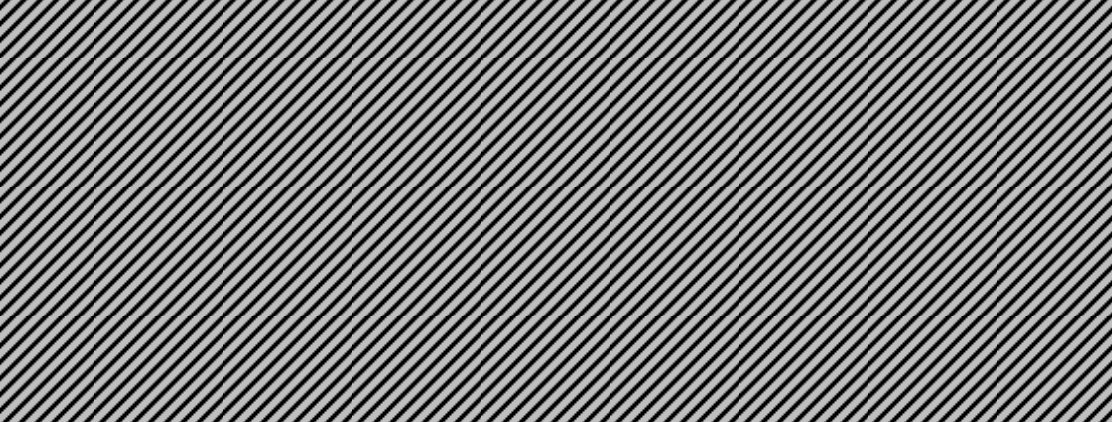

Figure 2. Frequency of the gene ADRA2B genotypes in patients with primary atrial fibrillation, their healthy relatives and persons of the control group.

Among patients with primary atrial fibrillation frequency of the genotypes appeared to be spread as follows: homozygous genotype (D/D) made $9,8 \pm 3,8 \%$ (6 persons), heterozygous genotype (I/D) - 52,5 $\pm 6,4 \%$ (32 persons), homozygous genotype in a rare allele (genotype I/I) $-37,7 \pm 6,2 \%$ (23 persons) (Table 6).

No significant differences were established between frequencies of I/D genotypes of the gene ADRA2B in patients with secondary atrial fibrillation, their healthy relatives and persons of the control group. (Table 6, Fig.3).

\begin{tabular}{|c|c|c|c|c|c|c|c|c|c|}
\hline \multirow[t]{2}{*}{ Genotypes } & \multicolumn{2}{|c|}{$\begin{array}{l}\text { Patients with } \\
\text { secondary atrial } \\
\text { fibrillation } \\
\quad \mathrm{N}=61\end{array}$} & \multicolumn{2}{|c|}{$\begin{array}{l}\text { Healthy relatives } \\
\qquad N=144\end{array}$} & \multicolumn{2}{|c|}{$\begin{array}{l}\text { Control group } \\
\qquad \mathrm{N}=91\end{array}$} & \multirow[t]{2}{*}{$\mathbf{p}_{1-2}$} & \multirow[t]{2}{*}{$\mathbf{p}_{1-3}$} & \multirow[t]{2}{*}{$\mathbf{p}_{2-3}$} \\
\hline & $\begin{array}{c}\text { Absolute } \\
\text { value }\end{array}$ & $\%$ & $\begin{array}{l}\text { Absolute } \\
\text { value }\end{array}$ & $\%$ & $\begin{array}{c}\text { Absolute } \\
\text { value }\end{array}$ & $\%$ & & & \\
\hline$D / D$ & 6 & $9,8 \pm 3,8$ & 17 & $11,8 \pm 2,7$ & 10 & $11 \pm 3,3$ & $p>0,05$ & $p>0,05$ & $p>0,05$ \\
\hline I/D & 32 & $52,5 \pm 6,4$ & 73 & $50,7 \pm 4,2$ & 58 & $63,7 \pm 5.0$ & $p>0,05$ & $p>0,05$ & $p>0,05$ \\
\hline $1 / 1$ & 23 & $37,7 \pm 6,2$ & 54 & $37,5 \pm 4,0$ & 23 & $25,3 \pm 4,6$ & $p>0,05$ & $p>0,05$ & $p>0,05$ \\
\hline
\end{tabular}

Note: Differences in the investigated parameters were calculated using the $x 2$ criterion.

Table 6. Frequency of the gene ADRA2B genotypes in patients with secondary atrial fibrillation, their healthy relatives and persons of the control group.

Therefore, summarizing the abovementioned, homozygous genotype I/I of the gene ADRA2B may be regarded as one of the genetic predictors of primary atrial fibrillation onset. The relatives of the probands with primary atrial fibrillation and homozygous genotype $\mathrm{I} / \mathrm{I}$ compose a high risk group for the appearance of this disorder. The conducted research of 
the gene ADRA2B polymorphism in patients with primary and secondary atrial fibrillation, can contribute to the decision of the etiological issue of hereditary atrial fibrillation.

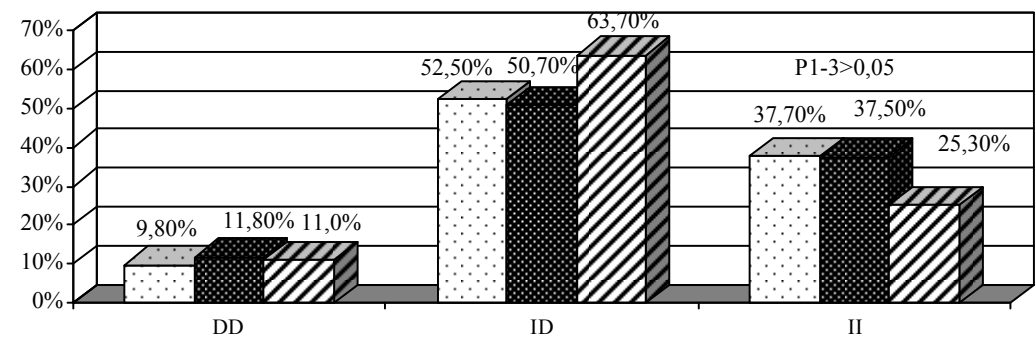

$\square 1$ Patients with secondary atrial fibrillation ( $\mathrm{n}=61)$. 2 Healthy relatives ( $\mathrm{n}=144) \boldsymbol{\nabla} 3$ Control group (n=91)

Figure 3. Frequency of the gene ADRA2B genotypes in patients with secondary atrial fibrillation, their healthy relatives and persons of the control group.

\subsection{Polymorphism of the endothelial NO synthase (eNOS) gene in probands with atrial fibrillation, their healthy relatives and persons of the control group}

In our work we investigated polymorphisms of the endothelial NO synthase (eNOS) gene in patients with atrial fibrillation, their healthy relatives and persons from the control group. According to the results of PCR in patients with atrial fibrillation, their healthy relatives and persons from the control group three sorts of $\mathrm{NO}$ synthase genotypes were revealed: $\mathrm{G} / \mathrm{G}-$ homozygous, G/T - heterozygous, T/T - homozygous.

Homozygous genotype $(894 \mathrm{G} / \mathrm{G})$ of the endothelial NO synthase (eNOS) gene in patients with atrial fibrillation was revealed in $58,5 \pm 4,8 \%$ (62 persons), heterozygous genotype (894 $\mathrm{G} / \mathrm{T}$ ) - in $39,6 \pm 4,8 \%$ (42 persons). Homozygous genotype in a rare allele ( $894 \mathrm{~T} / \mathrm{T}$ ) was genotyped in $1,9 \pm 1,3 \%$ (2 persons) (Table 7).

Among the probands' healthy relatives genotypes appeared to be spread as follows: homozygous genotype (894 G/G) -in 44,4 $\pm 4,1 \%$ (64 persons), heterozygous genotype $(894 \mathrm{G} / \mathrm{T})$ in $52,1 \pm 4,2 \%$ (75 persons), homozygous genotype in a rare allele $(894 \mathrm{~T} / \mathrm{T})$-in $3,5 \pm 1,5 \%(5$ persons) (Table 7). As for the control group, homozygous genotype (894 G/G) of the gene of endothelial NO synthase was revealed in $39,6 \pm 5,1 \%$ (36 persons), heterozygous genotype $(894 \mathrm{G} / \mathrm{T})$ - in 50,5 $\pm 5,2 \%$ (46 persons). Homozygous genotype in a rare allele $(894 \mathrm{~T} / \mathrm{T})$ was genotyped in $9,9 \pm 3,1 \%$ (9 persons) (Table 7).

A significant prevalence of homozygous genotype $G / G$ in patients with atrial fibrillation $(58,5 \%)$ as compared with the control group $(39,6 \%)$ is established; the difference is statistically reliable ( $p=0,039)$ (Table 7, Fig. 4). 


\begin{tabular}{|c|c|c|c|c|c|c|c|c|c|}
\hline \multirow[t]{2}{*}{ Genotypes } & \multicolumn{2}{|c|}{$\begin{array}{c}\text { Patients with atrial } \\
\text { fibrillation } \\
\mathrm{N}=106\end{array}$} & \multicolumn{2}{|c|}{$\begin{array}{l}\text { Healthy relatives } \\
\qquad \mathrm{N}=144\end{array}$} & \multicolumn{2}{|c|}{$\begin{array}{l}\text { Control group } \\
\qquad \mathrm{N}=91\end{array}$} & \multirow{2}{*}{$\mathbf{p}_{1-2}$} & \multirow{2}{*}{$p_{1-3}$} & \multirow{2}{*}{$\mathbf{p}_{2-3}$} \\
\hline & $\begin{array}{c}\text { Absolute } \\
\text { value }\end{array}$ & $\%$ & $\begin{array}{c}\text { Absolute } \\
\text { value }\end{array}$ & $\%$ & $\begin{array}{c}\text { Absolute } \\
\text { value }\end{array}$ & $\%$ & & & \\
\hline G/G & 62 & $58,5 \pm 4,8$ & 64 & $44,4 \pm 4,1$ & 36 & $39,6 \pm 5,1$ & $p>0,05$ & $p<0,05$ & $p>0,05$ \\
\hline$G / T$ & 42 & $39,6 \pm 4,8$ & 75 & $52,1 \pm 4,2$ & 46 & $50,5 \pm 5,2$ & $p>0,05$ & $p>0,05$ & $p>0,05$ \\
\hline $\mathrm{T} / \mathrm{T}$ & 2 & $1,9 \pm 1,3$ & 5 & $3,5 \pm 1,5$ & 9 & $9,9 \pm 3,1$ & $p>0,05$ & $P<0,05$ & $p>0,05$ \\
\hline
\end{tabular}

Note: Differences in the investigated parameters were calculated using the $\mathrm{x} 2$ criterion.

Table 7. Genotype frequency of the eNOS $894 \mathrm{G} / \mathrm{T}$ polymorphism in patients with atrial fibrillation, their healthy relatives and persons of the control group.

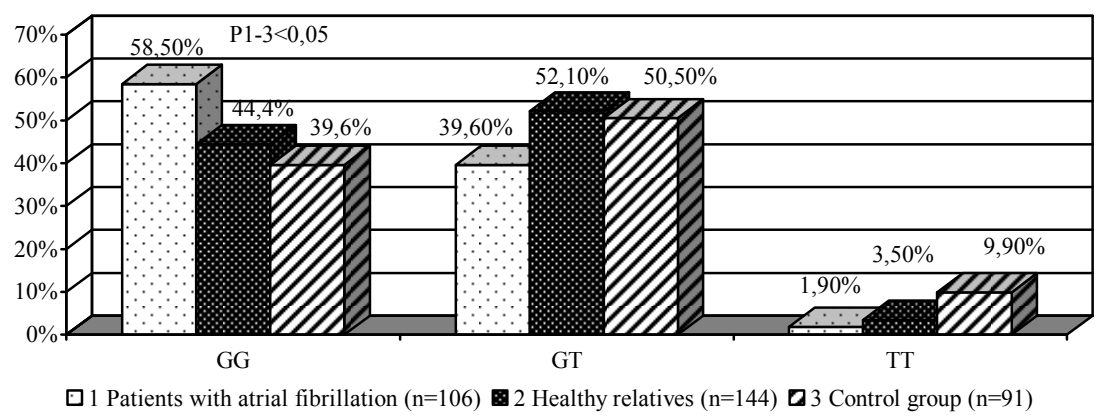

Figure 4. Genotype frequency of the eNOS $894 \mathrm{G} / \mathrm{T}$ polymorphism in patients with atrial fibrillation, their healthy relatives and persons of the control group.

In patients with primary atrial fibrillation homozygous genotype $(894 \mathrm{G} / \mathrm{G})$ of the endothelial NO synthase (eNOS) gene was revealed in $62,2 \pm 7,2 \%$ (28 persons), heterozygous genotype $(894 \mathrm{G} / \mathrm{T})$ - in $33,3 \pm 7,0 \%$ (15 persons), homozygous genotype in a rare allele $(894 \mathrm{~T} / \mathrm{T})$ was genotyped in $4,4 \pm 3,1 \%$ ( 2 persons) (Table 8 ).

A significant prevalence of homozygous genotype G/G as compared with the control group is established only in patients with primary atrial fibrillation, $62,2 \%$ и $39,6 \%$ respectively; the difference is statistically reliable $(p=0,021)$ (Table 8, Fig. 5). 


\begin{tabular}{|c|c|c|c|c|c|c|c|c|c|}
\hline \multirow[t]{2}{*}{$\begin{array}{c}\text { Genotyp } \\
\text { es }\end{array}$} & \multicolumn{2}{|c|}{$\begin{array}{l}\text { Patients with primary atrial } \\
\text { fibrillation } \\
\qquad N=45\end{array}$} & \multicolumn{2}{|c|}{$\begin{array}{l}\text { Healthy relatives } \\
\qquad \mathrm{N}=144\end{array}$} & \multicolumn{2}{|c|}{$\begin{array}{l}\text { Control } \\
\text { group } \\
\mathrm{N}=91\end{array}$} & \multirow[t]{2}{*}{$\mathbf{p}_{1-2}$} & \multirow[t]{2}{*}{$\mathbf{p}_{1-3}$} & \multirow[t]{2}{*}{$\mathbf{p}_{2-3}$} \\
\hline & Abs. & $\%$ & Abs. & $\%$ & Abs. & $\%$ & & & \\
\hline $\mathrm{G} / \mathrm{G}$ & 28 & $62,2 \pm 7,2$ & 64 & $44,4 \pm 4,1$ & 36 & $\begin{array}{c}39,6 \pm 5 \\
1\end{array}$ & $p>0,05$ & $p<0,05$ & $p>0,05$ \\
\hline $\mathrm{G} / \mathrm{T}$ & 15 & $33,3 \pm 7,0$ & 75 & $52,1 \pm 4,2$ & 46 & $\begin{array}{c}50,5 \pm 5 \\
2\end{array}$ & $p>0,05$ & $p>0,05$ & $p>0,05$ \\
\hline $\mathrm{T} / \mathrm{T}$ & 2 & $4,4 \pm 3,1$ & 5 & $3,5 \pm 1,5$ & 9 & $9,9 \pm 3,1$ & $p>0,05$ & $P>0,05$ & $p>0,05$ \\
\hline
\end{tabular}

Note: Differences in the investigated parameters were calculated using the $\mathrm{x} 2$ criterion.

Table 8. Genotype frequency of the eNOS $894 \mathrm{G} / \mathrm{T}$ polymorphism in patients with primary atrial fibrillation, their healthy relatives and persons of the control group.

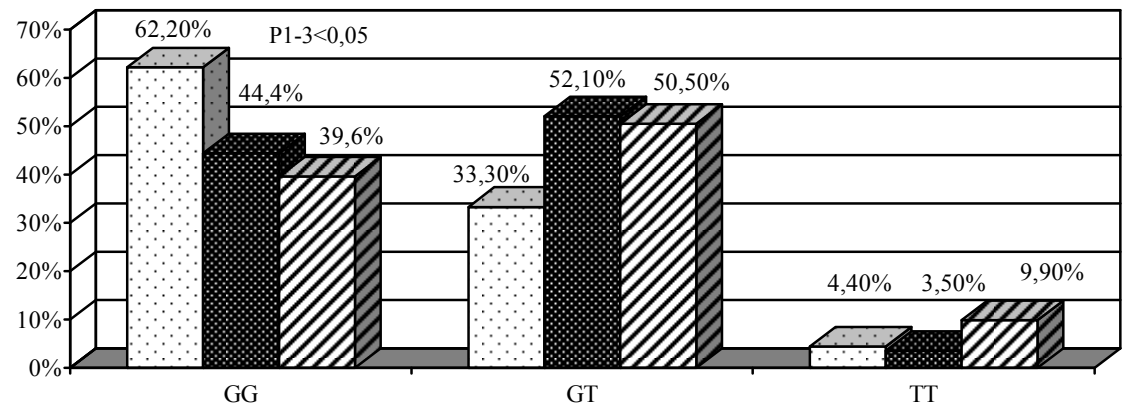

$\square 1$ Patients with primary atrial fibrillation $(\mathrm{n}=106) \mathbf{2}$ Healthy relatives (n=144) $\boldsymbol{\square} 3$ Control group ( $\mathrm{n}=91)$

Figure 5. Genotype frequency of the eNOS $894 \mathrm{G} / \mathrm{T}$ polymorphism in patients with primary atrial fibrillation, their healthy relatives and persons of the control group.

In patients with secondary atrial fibrillation homozygous genotype (894 G/G) of the endothelial NO synthase (eNOS) gene was revealed in 55,7 $\pm 6,4 \%$ (34 persons), heterozygous gen-

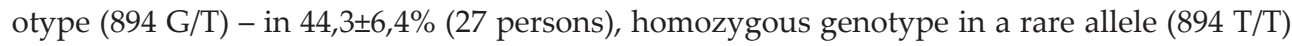
was not genotyped (Table 9).

No significant differences were established between frequencies of genotypes of the endothelial NO synthase (eNOS) gene in patients with secondary atrial fibrillation, their healthy relatives and persons of the control group (Table 9, Fig. 6). 


\begin{tabular}{|c|c|c|c|c|c|c|c|c|c|}
\hline \multirow[t]{2}{*}{ Genotypes } & \multicolumn{2}{|c|}{$\begin{array}{l}\text { Patients with } \\
\text { secondary atrial } \\
\text { fibrillation } \\
\quad N=61\end{array}$} & \multicolumn{2}{|c|}{$\begin{array}{l}\text { Healthy relatives } \\
\qquad N=144\end{array}$} & \multicolumn{2}{|c|}{$\begin{array}{l}\text { Control group } \\
\qquad \mathrm{N}=91\end{array}$} & \multirow[t]{2}{*}{$\mathbf{p}_{1-2}$} & \multirow[t]{2}{*}{$\mathbf{p}_{1-3}$} & \multirow[t]{2}{*}{$\mathbf{p}_{2-3}$} \\
\hline & $\begin{array}{c}\text { Absolute } \\
\text { value }\end{array}$ & $\%$ & $\begin{array}{c}\text { Absolute } \\
\text { value }\end{array}$ & $\%$ & $\begin{array}{c}\text { Absolute } \\
\text { value }\end{array}$ & $\%$ & & & \\
\hline $\mathrm{G} / \mathrm{G}$ & 34 & $55,7 \pm 6,4$ & 64 & $44,4 \pm 4,1$ & 36 & $39,6 \pm 5,1$ & $p>0,05$ & $p>0,05$ & $p>0,05$ \\
\hline $\mathrm{G} / \mathrm{T}$ & 27 & $44,3 \pm 6,4$ & 75 & $52,1 \pm 4,2$ & 46 & $50,5 \pm 5,2$ & $p>0,05$ & $p>0,05$ & $p>0,05$ \\
\hline$T / T$ & 0 & 0 & 5 & $3,5 \pm 1,5$ & 9 & $9,9 \pm 3,1$ & $p>0,05$ & $P>0,05$ & $p>0,05$ \\
\hline
\end{tabular}

Note: Differences in the investigated parameters were calculated using the $\mathrm{x} 2$ criterion.

Table 9. Genotype frequency of the eNOS $894 \mathrm{G} / \mathrm{T}$ polymorphism in patients with secondary atrial fibrillation, their healthy relatives and persons of the control group.

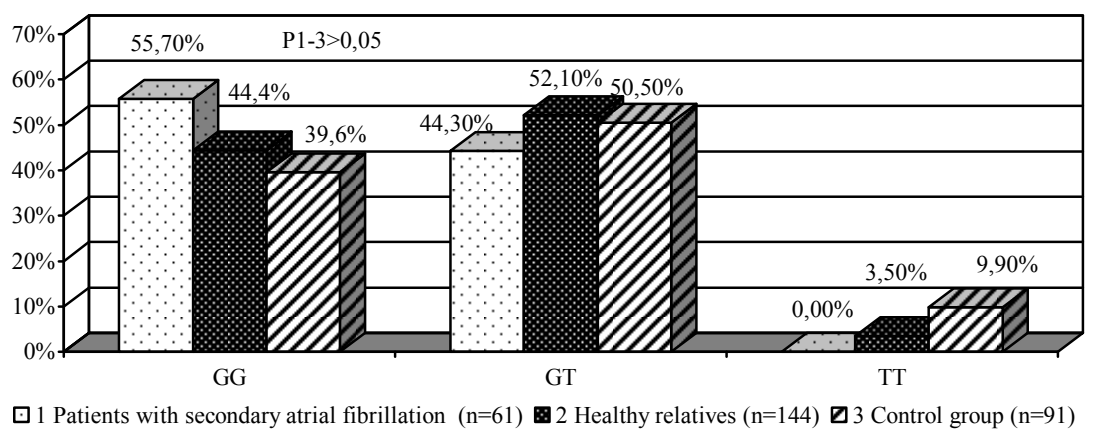

Figure 6. Genotype frequency of the eNOS 894 G/T polymorphism in patients with secondary atrial fibrillation, their healthy relatives and persons of the control group.

As was mentioned above, the decrease in the production of NO-synthase can cause oxidative stress, lead to disturbances in cardiac conduction system and provoke the re-entry mechanism in the atria, thereby contributing to the development of atrial fibrillation [42, 44].

This paper demonstrates a significant prevalence of homozygous genotype G/G of the endothelial NO synthase (eNOS) gene in patients with primary atrial fibrillation. Specifically, polymorphism of the endothelial NO synthase (eNOS) gene causes the decrease in the level of NO and calcium in the cells as well as disturbances in the physiological process of HMFdependent protein kinases synthesis, all these factors contributing to the development of atrial fibrillation.

The investigated genetic markers may be used in diagnosing of primary atrial fibrillation susceptibility. 


\section{Conclusion}

A significant prevalence of homozygous genotype I/I of the gene ADRA2B in patients with primary atrial fibrillation $(44,4 \%)$ as compared with the control group $(25,3 \%)$ is established.

The relatives of the probands with primary atrial fibrillation and homozygous genotype I/I can be subsumed under the risk group for the development of this pathology. Changes in the aminoacid profile of the third intracellular loop of the $\alpha 2 \beta$ - adrenergic receptor due to the polymorphism I/I of the ADRA2B gene disturb the interaction of the receptor with effector proteins (G-protein or receptor protein kinase), which cause changes in receptor activity autoregulation or associated with the activity cAMP processes of intracellular signaling (e.g. migration of the Ca from intracellular stores to the cytosol).

A significant prevalence of homozygous genotype $\mathrm{G} / \mathrm{G}$ of the endothelial NO synthase (eNOS) gene in patients with primary atrial fibrillation $(62,2 \%)$ as compared with the control group $(39,6 \%)$ is shown.

The relatives of the probands with primary atrial fibrillation and homozygous genotype $\mathrm{G} / \mathrm{G}$ can be subsumed under the risk group for the development of this pathology.

A certain role in atrial fibrillation pathogenesis can be played by nitrogen oxide molecules (NO). Nitrogen oxide is constantly produced in the human organism enzymatically from L arginine and performs a function of a universal messenger in intracellular signaling [19]. NO synthase (NOS, EC number 1.14.13.39) is a catalyst in this reaction [19]. Under the influence of NOS L - arginine oxidation and nitrogen oxide synthesis takes place in vessel endotheliocytes. Then, going from the endotheliocytes to the smooth muscle cells, NO labilizes soluble guanylate cyclase, thereby contributing to the decrease in the level of the rhythmic hydroxymethylfurfurol (HMF), activation of the rhythmic HMF - dependent protein kinases, changes in Ca concentration, susceptibility of the conducting cardiac myocytes receptors to the level of catecholamines. In case of polymorphism G/G of the endothelial NO synthase (eNOS) gene the level of nitrogen oxide and intracellular Ca decreases, the physiological process of HMF-dependent protein kinases synthesis is disturbed, which contributes to the development of heart rhythm disorders.

We studied the eNOS $894 \mathrm{G} / \mathrm{T}$ polymorphism in the group of patients described above.

As was mentioned above, the decrease in the production of NO-synthase can cause oxidative stress and changes in cardiac conduction system, thereby contributing to the development of atrial fibrillation [45].

Continuing the search of candidate genes of the primary and secondary atrial fibrillation and the study of different genes polymorphisms combinations, which are likely to cause the development of atrial fibrillation seems to be necessary.

The final result of these investigations can be genetic identification of the atrial fibrillation risk groups, early diagnostics, ранняя диагностика, specific atrial fibrillation preventive care as well as on-time treatment of this type of arrhythmia. 
Acknowledgment We would like to thank Mikhail Voevoda, Vladimir Maksimov and staff of the Research Institute of Therapy, Novosibirsk, Russia for their help in genetic testing and their continued support and assistance in our investigations.

\section{Author details}

Svetlana Nikulina ${ }^{1}$, Vladimir Shulman ${ }^{1}$, Ksenya Dudkina $^{1}$, Anna Chernova $^{1}$ and Oksana Gavrilyuk ${ }^{2}$

1 Krasnoyarsk State Medical University named after Prof. V.F. Voino-Yasenetsky, Department of internal diseases No. 1, Krasnoyarsk, Russia

2 Krasnoyarsk State Medical University named after Prof. V.F. Voino-Yasenetsky, Department of Latin and foreign languages, Krasnoyarsk, Russia

\section{References}

[1] Diagnostika i lechenie fibrilljacii predserdij: Rossiyskie rekomendatsii. Terapevt 2005; (1/2) 11-37.

[2] Benjamin EJ., Wolf PA., Dagostino RB. et al. Impact of atrial fibrillation on the risk of death: the Fremingam Heart Study. Circulation 1998;98(4) 946-952.

[3] Kannel WB., Abbott RD., Savage DD. Epidemiologic faetures of chronic atrial fibrillation: the Framingham study/ N. Engl. J. Med 1982; 306 1018-1022.

[4] Lloid-Jones DM., Wang TJ., Leip E.P.et al. Lifetime risk for development of atrial fibrillation: the Fremingam Heart Study. Circulation 2004;110(5) 1042-1046.

[5] Shulman V.A., Nikulina S.Yu., Ivanitskaya Yu.V. i dr. Idiopaticheskie (pervichnye) zabolevaniya provodyaschey sistemy serdtsa. Kardiologiya 2000;1 89-92.

[6] Lai LP., Tsai CC., Su MJ. et al. Atrial fibrillation is association with accumulation of aging-related common type mytochondrial DNA deletion mutation in human atrial tissue. Chest 2003; 123 539-544.

[7] Christophersen IE., Ravn LS., Budtz-Jooergensen E. et al. Familial aggregation of atrial fibrillation a study in Danish twins. Circ. Arrhythm. Electrophisiol 2009;2(2) 378-383.

[8] Surawicz HJ. Vidaillet M., Lev B. et. al. Familial congenital sinus rhythm anomalies: clinical and pathological correlations. Pacing Clin. Electrophysiol 1992;15(11) 1720-1729.

[9] Fox C.S, Parise H.,. Agostino R.B et al. Parental atrial fibrillation as a risk for atrial fibrillation in offspring. JAMA 2004; 291 2851-2855. 
[10] Roberts DJ., Michael H., Gollob M.H. Impact of genetic discoveries on the classification of lone atrial fibrillation. J. Am. Coll. Cardiol 2010;55(8) 705-711.

[11] Bharati S., Surawicz B., Vidaillet HJ. Familial congenital sinus rhythm anomalies: clinical and pathological correlations. PACE 1992; 15 (Pt. 1) 1720-1729.

[12] Wolf L. Familial auricular fibrillation. N. Engl. J. Med 1943; 229 396-397.

[13] Lomasney JW., Lorenz W., Allen LF. et al. Expansion of the $\alpha 2$-Adrenergic Receptor Family: Cloning and characterization of a human $\alpha 2$-adrenergic receptor subtype, the gene for which is located on chromosome 2. Proc. Natl. Acad. Sci. USA 1990; 87 (13) 5094-5098.

[14] Hein L., Altman JD., Kobilka BK. Two functionally distinct alpha2-adrenergic receptors regulate sympathetic neurotransmission. Nature 1999; 402 (6758) 181-184.

[15] Wowern F., Bengtsson K., Lindblad U. et al. Functional variant in the (alpha)2B adrenoceptor gene, a positional candidate on chromosome 2, associates with hypertension. Hypertension 2004;43(3) 231-233.

[16] Hjalmarson A. Heart rate and beta-adrenergic mechanisms in acute myocardial infarction. Basic Res. Cardiol 1990; 85 325-333.

[17] Koch WJ., Lefkowitz J., Rockman HA. Functional consequences of altering myocardial adrenergic receptor signaling. Annu. Rev. Physiol 2000; 62 237-260.

[18] Coumel P. Neurogenic and humoral influences of the autonomic nervous system in the determination of paroxysmal atrial fibrillation. The atrium in health and disease. N. Y.: Futura Publ. Co.; 1982. p213-232.

[19] Pokrovsky VI. Oksid azota, ego fiziologicheskie i patofiziologicheskie svoystva. Terapevt. Arhiv. 2005;1 82-87.

[20] Kim M. Myocardial Nox2 containing NAD(P)H oxidase contributes to oxidative. Stress in human atrial fibrillation. Circ. Res 2005; 97 629-636.

[21] Wolf L. Familial auricular fibrillation. N. Engl. J. Med.; 1943. p396-397.

[22] Dzyak VN. Mercatel'naya aritmiya. Kiev: Zdorovye; 1979.

[23] Tikanoja T. Familial atrial fibrillation with fetal onset. Jpn. Heart J 1998; 79 (2) 195-197.

[24] Boitsov SA. Mercatel'naya aritmiya. SPb: ELBI; 2001.

[25] Zharko KP. O semeynyh formah narusheniya ritma serdtsa i provodimosti. Vracheb. delo 1981;7 67-68.

[26] Zav'yalov AI., Zav'yalov DA. Serdtse i myshechnaya rabota. Aktual'nye voprosy biomedicinskoy i klinicheskoy antropologii: mater. konf. Krasnoyarsk 1997 35-36.

[27] Poret P., Mabo P., Deplace C. Is isolated atrial fibrillation genetically determined? Apropos of a familial history. Arch. Mol. Coeur. Vaiss 1996;89(9) 1197-1203. 
[28] Girona J., Domingo A., Albert D. et al. Fibrillation auricular familiar.Rev. Esp. Cardiol 1997;50(8) 548-551.

[29] Gillor A., Korsch E. Familial manifestation of idiopathic atrial flutter. Monatsschr. Kinderheilkd 1992;140(1) 47-50.

[30] Brugada R. Genetic bases of arrhythmias. Rev. Esp. Cardiol 1998; 51 p. 274-285.

[31] Brugada R., Tapscott T. et al. Identification of a genetic locus for familial atrial fibrillation. N. Engl. J. Med; 1997. p905-911.

[32] Yang H., Xia M., Jin Q. Identification of a KCNE2 - gain of function mutation in patients with familial atrial fibrillation. Am. J. Pathol 2004;165(3) 1010-1032.

[33] Christiansen J., Dyck JD., Elyas BG. et al. Chromosome 1q21.1 contiguous gene deletion is associated with congenital heart disease. Circ. Res 2004;94(11) 1249-1435.

[34] Firouzi M., Ramanna H., Kok B. et al. Association of human connexin 40 gene polymorfisms with atrial vulnerability as a risk factor for idiopatic atrial fibrillation. Circ. Res 2004;5 29.

[35] Gensini F., Padeleti L., Fatini C. et al. Angiotensin-converting ensyme and endothelial nitric oxide synthase polymorpisms in patients with atrial fibrillation. Am. J. Cardiol 2003;91 678-683.

[36] Tsai CC., Lai LP., Chang FC. et al. Renin-angiotensin gene polymorphism and atrial fibrillation. Clin. Sci 2004; 653- 659.

[37] Tseluyko VI., Dmitriev SJu. Rol' interstitsial'nogo fibroza kak prediktora vozniknoveniya fibrillyatsii predserdy. Medicina neotlozhnyh sostojany 2007;3 124-126.

[38] Minushkina LO., Zateycshikov DA., Zateycshikova AA. i dr. Polimorfizmy gena endotelial'noj NO - sintazy i gipertrofii miokarda u bol'nyh arterial'noy gipertenziey. Kardiologiya 2002;3 30-34.

[39] Minushkina LO., Gorshkova ES. i dr. Rol' geneticheskih faktorov v razvitii mertsatel'noy aritmii. Kardiologiya 2007;12 57-62.

[40] Otway R., Vandenberg JI., Guo G. et al. Stretch-sensitive KCNQ1 mulation: a link between genetic and environmental factors in the pathogenesis of atrial fibrillation. J. Am. Coll. Cardiol 2007; 49 p. 578-586.

[41] Simard C., Drolet B., Yang P. et al. Polymorphism screening in the cardiac K+ channel gene KCNA5. Clin. Pharmacol. Ther 2005;77 138-141.

[42] Chen H., Chu H., Shi Y. et al. Association between endothelial nitric oxide synthase polymorphisms and atrial fibrillation: a meta-analysis. J Cardiovasc Transl Res 2012;528-534.

[43] Liu T, Korantzopoulos P, Xu G. et al. Association between angiotensin-converting enzyme insertion/deletion gene polymorphism and atrial fibrillation: a meta-analysis. Europace 2011;346-354. 
[44] Gurevich MA. Mertsatel'naya aritmiya. Voprosy etiologii, klassifikatsiya i lechenie // Klinich.meditsina 2006;2 7-15.

[45] Daoude E. Effect of atrial fibrillation on atrial refractoriness in humans. Circulation 1996; 94 p.1600 - 1606. 
